\title{
Accustoms Gamification in Education Improves Student Motivation, Engagement and Academic Performance
}

\author{
Shariful Hafizi Md Hanafiah, Kamarul Shukri Mat Teh, Mohd Fadzil Abdul Kadir
}

\begin{abstract}
Gamification involves game-thinking and game mechanics process to encourage user motivation, engagement and influencing them to achieve problem solving. Gamification in education refers to the use of game mechanics and dynamics as a strategy to infuse ordinary activities or processes to support 21st century learning and facilitation process. Through Malaysia Ministry of Education 1BestariNet project, a virtual learning environment labelled as Frog provided by YTL Communications Sdn Bhd was introduced to support elearning in Malaysian government schools. Frog VLE combines conventional education concept with cloud computing technologies where learning and facilitation can be done ubiquitously twenty-four hours a day and seven days a week, via computing devices with Internet connection. This article describes gamification in education through Frog VLE module known as FrogPlay to infuse students motivation, engagement and academic performance.
\end{abstract}

Index Terms - Academic performance, engagement, gamification, motivation, VLE.

\section{INTRODUCTION}

In [1] has reported and demonstrated that e-learning market size is worth more than USD165 billion in 2015 and is targeted to grow by 5\% between 2016-2023 with an estimated value reaching USD 240 billion. Among the other interesting things, in [1] has predicted growth in e-learning is the influence and use of gamification.

Gamification been defined as the uses gamification and its experience beyond the context of video games [2]-[6]. Google Trends (https://trends.google.com/trends/) exemplifies gamification is a notable trend. Fig. 1 and 2 show an upward tendency and popularity of gamification terms around the globe and Malaysia over the last 10 years from 2008 to 2018.

In [7] reports that Malaysia accumulated game revenue at USD539.5 million and listed as one of the top 20 countries in game revenue. 22.8 million $(67.5 \%)$ Malaysian been considered as online population, also known as digital natives [8], with its population at 30.8 million people [7]. These online population or digital natives are always tangled around with technologies or gadgets in their daily tasks. Statistically proves the growth and popularity of video games amongst Malaysians. Therefore, gamification in

Revised Manuscript Received on July 10, 2019.

Shariful Hafizi Md Hanafiah, Faculty of Islamic Contemporary Studies, Sultan Zainal Abidin University, Terengganu, Malaysia.

Kamarul Shukri Mat Teh, Faculty of Islamic Contemporary Studies, Sultan Zainal Abidin University, Terengganu, Malaysia.

Mohd Fadzil Abdul Kadir, Faculty of Informatics and Computing, Sultan Zainal Abidin University, Terengganu, Malaysia. education has potential to facilitate, implement and explore in students learning.

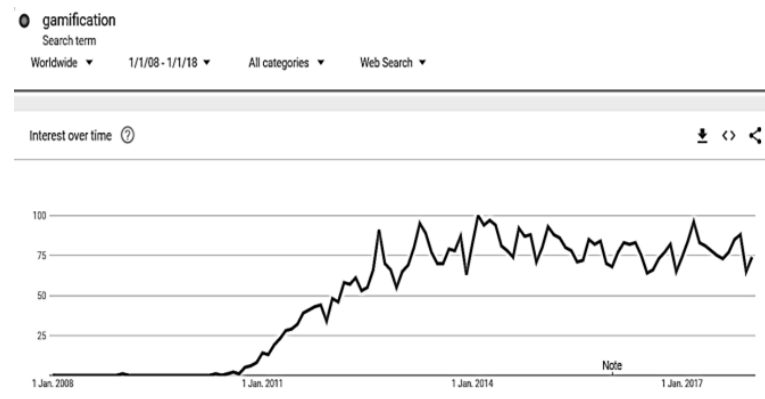

Fig. 1: Trends and popularity of gamification search terms worldwide for the last 10 years (2008-2017)

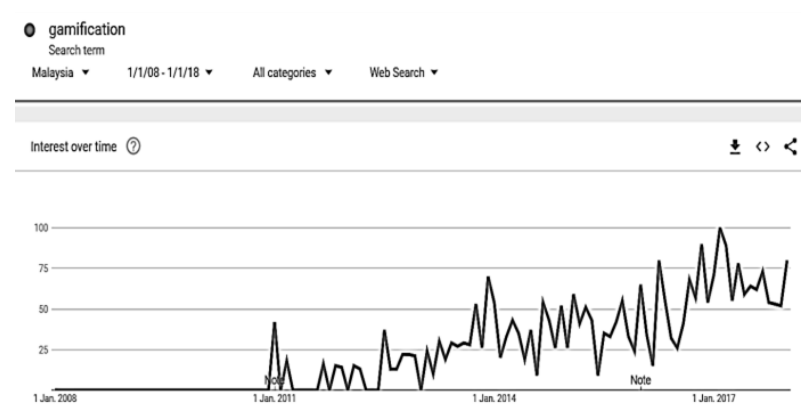

Fig. 2: Trends and popularity of gamification search terms in Malaysia for the last 10 years (2008-2017)

\section{GAMIFICATION IN EDUCATION IMPROVES STUDENTS MOTIVATION, ENGAGEMENT AND ACADEMIC PERFORMANCE}

Gamification has prospective to be extensively used in countless fields to solve human behavioral change [9]. The main reason is because of its abilities and possible to excite motivation and engagement [10]. 24 peer-reviewed gamification empirical studies was successful and very context-dependent when different intrinsic and extrinsic motivators are associated with the different activities for engagement [11].

Gamification has been identified as one of the most important ideas and has the prospect in education and termed as gamification in education [12]. Gamification in education is a current strategy that gains popularity in elearning by using the mechanics and dynamics of video games in education context [13]-[15].

Published By: 


\section{ACCUSTOMS GAMIFICATION IN EDUCATION IMPROVES STUDENT MOTIVATION, ENGAGEMENT AND ACADEMIC PERFORMANCE}

More than $26 \%$ gamification implementation in education dominates publications and scientific research [16]. Amongst the reasons are its students friendly competitive environments that exists in gamification can influence students motivation and engagement [17]. Apart from that, development of skills also can be gained through gamification [18].

With the purpose to preserve these digital natives generation motivation and engagement, different motivational tactics, approaches and applications with the means of gamification can achieve and gives impact cognitively [19]. For these digital natives, traditional learning and pedagogical tools in current educational support systems might be too restraining and old-fashioned. Most common types of gamification on learning research designates the assessment of existing systems or offering solutions to the learning problems encompasses motivational changes, students engagement levels and improved academic achievements [20].

Currently widespread gamification practice amongst the digital generation are Game-based Classroom Response System (GCRS). Based on a quiz concept, GCRS tools and platforms such as Kahoot, Quizizz and Socrative aims to enable and ease interactive teaching and learning activities. Besides from self-assessment tenacities, employing GCRS positively affect the students attendance [21] when they have a fun and engaging GCRS atmosphere while scoring points for each correct answers.

Students relatively agree, readymade GCRS tools or platform such as Kahoot, Quizizz and Socrative can support their learning by increases their motivation, engagement, enjoyment, concentration, satisfaction and academic performance [22], [23]. Besides that, custom and selfdeveloped GCRS also can help students learning and understands better [24].

Nevertheless, computer games by themselves are not sufficient or enough for learning to occur [25]. Therefore, it is suggested to combine and design learning by activating gamification features can support and enhance student learning [26]. These gamification features act as a trigger to ignite repetitive game cycle in learning. The repetitive game cycle increase effects on student motivation and active involvement. Specific objective achievement in learning outcomes also will be gained when the student are highly motivated and actively engage in learning session.

\section{GAMIFICATION FOLDS WITH FROGPLAY \& RESULTS}

Implementation of 1 BestariNet (1BN) project by Malaysia Ministry of Education (MoE) allows Malaysian government schools to use Frog VLE as an integrated solution. Frog enables learning and facilitation, collaborations and school administrated agendas using Internet technology [27], [28]. Frog VLE is one of the flexible cloud based learning system that available in elearning platform that can be accessed within or outside the school compound. Frog integrates conventional learning concepts with virtual technologies [27].

FrogPlay is a built in revision module in Frog VLE. FrogPlay uses gamification concepts to stimulate and support student learning by enriching the student's

experience by answering online quizzes through Frog VLE. FrogAsia also provided a dedicated workshop known GULAI (Game Up Learning and Involvement) for teachers for support to introduce FrogPlay as a rehearsing module for students through existing quizzes, mini games and performance reports [27].

FrogPlay aimed to continuously motivating and engaging students do revisions. To ensure and motivate students to learn while making the learning activity enjoyable, FrogPlay (1) presenting questions to students which did not need too much thoughtful with the intention to avoid situating heavy mental or cognitive loads, (2) using time limitation as moderate pressure on students to answer questions, and (3) encouraging students participation to be voluntary and hence not assessing the activity.

After logging into Frog VLE, student get to access student room view as shown in Fig. 1 after launching the FrogPlay [27]. Table 1 shows the FrogPlay menu or feature descriptions that can be accessed by students.

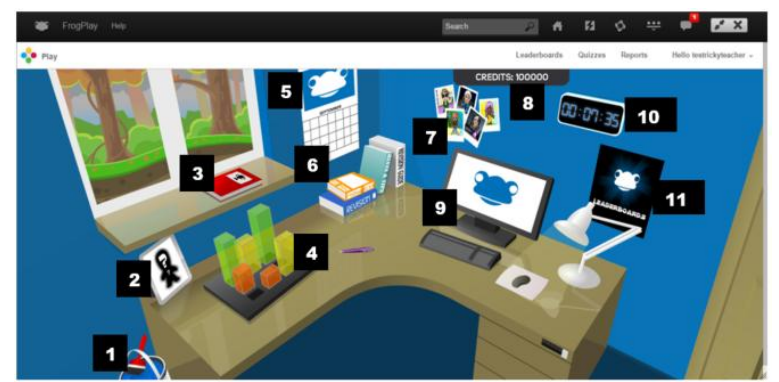

Fig. 3: Student room view can be access after FrogPlay module is successfully launched

Table 1: FrogPlay menu or features descriptions

\begin{tabular}{|c|c|c|}
\hline No. & Menu/Features & Description \\
\hline 1 & Wallpaper & $\begin{array}{l}\text { Students can customised their } \\
\text { wallpaper according to their } \\
\text { personal taste. }\end{array}$ \\
\hline 2 & Profile & $\begin{array}{l}\text { Students can create and edit } \\
\text { avatars. This Avatar acts as a } \\
\text { virtual representation of students in } \\
\text { FrogPlay. }\end{array}$ \\
\hline 3 & Achievements & $\begin{array}{l}\text { Students can review and setup } \\
\text { targets or achievement levels in } \\
\text { every game that has been played. }\end{array}$ \\
\hline 4 & Reports & $\begin{array}{l}\text { Students can see their performance } \\
\text { for each exercises or quizzes that } \\
\text { has been answered. }\end{array}$ \\
\hline 5 & Pets & $\begin{array}{l}\text { Students can buy pets. Through the } \\
\text { pets been owned, digital games } \\
\text { specifically for pets and extra } \\
\text { rewards will be available. }\end{array}$ \\
\hline 6 & Assignments & $\begin{array}{l}\text { Students answer quiz questions } \\
\text { that have been developed by } \\
\text { teachers according to the school } \\
\text { subjects. }\end{array}$ \\
\hline 7 & Buddies & $\begin{array}{l}\text { Unlike social media, students can } \\
\text { only add friends they know and } \\
\text { want to compete in ErogPlay. }\end{array}$ \\
\hline & ciences Public & sering \\
\hline
\end{tabular}




\begin{tabular}{|c|c|l|}
\hline 8 & Credits & $\begin{array}{l}\text { Total points or scores collected by } \\
\text { students earned through activities } \\
\text { performed within FrogPlay. }\end{array}$ \\
\hline 9 & Revisions & $\begin{array}{l}\text { Students doing revision by } \\
\text { accessing and responding to } \\
\text { quizzes. }\end{array}$ \\
\hline 10 & Revision time & $\begin{array}{l}\text { Total amount of time students has } \\
\text { spent on revision within FrogPlay. }\end{array}$ \\
\hline 11 & Leaderboards & $\begin{array}{l}\text { Students can view their avatar and } \\
\text { scores based on the game that was } \\
\text { played during the quiz. These } \\
\text { scores sort by ranking from the } \\
\text { highest to the lowest scores. }\end{array}$ \\
\hline
\end{tabular}

The gamified learning activity using FrogPlay will be done in two fragments [29]. For first fragments, the students actively engaging (answering) the quiz after being instructed by the teacher. Students can start and complete the quiz not synchronized, depending on how quickly students answer all the questions. Student result (points) will be appear on the FrogPlay leaderboard when successfully completed the quiz. Player rankings change as new results were posted to the leaderboard (real-time effect) that signifies and acknowledge student engagement and performance. Hence, the quiz results achieved will ignite excitement and encourage students for debriefing session with the teacher during the second fragment. The second fragment occurs after the leaderboard acknowledged and projected students' results. The objective is to ensure teacher and students scaffolds learning in order to achieve learning objectives or outcomes hence forward eases students comprehension of the topic.

\section{CONCLUSION}

This article fixated on the foundation of students can remember $90 \%$ of what they learned, even if only a simulation when they involves in the activity or tasks [30]. Usually students only can recall $10 \%$ through reading, $20 \%$ through hearing, 30\% if associated with visuals during oral presentation and remembers $50 \%$ while observe an explanation by someone and carrying out with an action. Gamification as an educational tool allows the students to accomplish the learning tasks to acquire mastery at their own pace while accompanied with fun and enjoyment.

\section{ACKNOWLEDGMENT}

This research was supported by Research Management and Innovation Centre, Universiti Sultan Zainal Abidin.

\section{REFERENCES}

1. Docebo, ELearning market trends and forecasts 2017-2020. Georgia: Docebo, 2016.

2. S. Deterding, M. Sicart, L. Nacke, K. O'Hara, and D. Dixon, "Gamification: Using game design elements in non-game contexts," Annual Conference Extended Abstracts on Human Factors in Computing Systems, 2011, pp. 2425-2428.

3. S. Deterding, D. Dixon, R. Khaled, and L. Nacke, "From game design elements to gamefulness: Defining gamification," ACM 15th International Academic MindTrek Conference on Envisioning Future Media Environments, 2011, pp. 9-15.
4. S. Deterding, R. Khaled, L. Nacke, and D. Dixon, "Gamification: Toward a definition," Gamification Workshop Proceedings, 2011, pp. 1-4.

5. R. Eppmann, M. Bekk, and K. Klein, "Gameful experience in gamification: Construction and validation of a Gameful Experience Scale [GAMEX]," Journal of Interactive Marketing, 43, 2018, pp. 98-115.

6. L. E. Nacke, and S. Deterding, "The maturing of gamification research," Computers in Human Behavior, 71, 2017, pp. 450454.

7. Newzoo, 2016 global games market report: Trends, insights and projections toward 2019. Available: https://newzoo.com/wpcontent/uploads/2016/01/Newzoo_2016_Global_Games_Mar ket_Report_Dummy.pdf.

8. J. McGonigal, Reality is Broken: Why Games Make Us Better and How They Can Change the World. New York: Penguin, 2011.

9. R. Dyer, "A conceptual framework for gamification measurement," in Gamification in Education and Business, T. Reiners and L. Wood, Eds. Cham: Springer, 2015, pp. 47-66.

10. L. Z. Pedro, A. M. Z. Lopes, B. G. Prates, J. Vassileva, and S. Isotani. "Does gamification work for boys and girls? An exploratory study with a virtual learning environment," 30th Annual ACM Symposium on Applied Computing, 2015, pp. 214-219.

11. J. Hamari, J. Koivisto, and H. Sarsa, "Does gamification work? A literature review of empirical studies on gamification," 47th Hawaii International Conference on System Sciences, 2014, pp. 3025-3034.

12. S. N. M. Mahfuzah, S. Sazilah, and B. Norasiken, "An analysis of gamification elements in online learning to enhance learning engagement," 6th International Conference on Computing and Informatics, 2017, pp. 452-460.

13. B. Barna, and S. Fodor, "An empirical study on the use of gamification on IT courses at higher education," International Conference on Interactive Collaborative Learning, 2017, pp. 684-692.

14. K. Davis, H. Sridharan, L. Koepke, S. Singh, and R. Boiko. "Learning and engagement in a gamified course: Investigating the effects of student characteristics," Journal of Computer Assisted Learning, 34(5), 2018, pp. 492-503.

15. M. S. N. Mahfuzah, S. N. S. Safwana, and M. S. Mohd Azran, "Gamification approach in education to increase learning engagement," International Journal of Humanities, Arts and Social Sciences, 4(1), 2018, pp. 22-32.

16. K. Seaborn, and D. I. Fels, "Gamification in theory and action: A survey," International Journal of Human Computer Studies, 74, 2015, pp. 14-31.

17. M. Papastergiou, "Digital game-based learning in high school Computer Science education: Impact on educational effectiveness and student motivation," Computers and Education, 52(1), 2009, pp. 1-12.

18. A. Prambayun, M. S. M. Suyanto, and A. Sunyoto, "Model gamifikasi untuk sistem manajemen pembelajaran," Semnasteknomedia Online, 4(1), 2016, pp. 2-6.

19. S. Mageswaran, A. Zaleha, and M. Z. Norasykin, "Gamification: Cognitive impact and creating a meaningful experience in learning," IEEE 6th Conference on Engineering Education, 2014, pp. 123-128.

20. S. D. S. Borges, V. H. S. Durelli, H. M. Reis, and S. Isotani, "A systematic mapping on gamification applied to education," 29th Annual ACM Symposium on Applied Computing, 2014, pp. 216-222. 


\section{ACADEMIC PERFORMANCE}

21. H. Z. Abidin, and F. H. K. Zaman, "Students' perceptions on game-based classroom response system in a computer programming course," IEEE 9th International Conference on Engineering Education, 2017, pp. 254-259.

22. Y. Chaiyo, and R. Nokham, "The effect of Kahoot, Quizizz and Google Forms on the student's perception in the classrooms response system," IEEE 2nd Joint International Conference on Digital Arts, Media and Technology, 2017, 178-182.

23. A. I. Wang, M. Zhu, and R. Sætre, "The effect of digitizing and gamifying quizzing in classrooms," Academic Conferences and Publishing International, 2016, pp. 1-10.

24. J. Zhang, M. Atay, E. Smith, E. R. Caldwell, and E. J. Jones, "Using a game-like module to reinforce student understanding of recursion," IEEE Frontiers in Education Conference, 2014 pp. 1-7.

25. H. F. O'Neil, R. Wainess, and E. L. Baker, "Classification of learning outcomes: Evidence from the computer games literature," Curriculum Journal, 16(4), 2005, pp. 455-474.

26. R. Garris, R. Ahlers, and J. E. Driskell, "Games, motivation, and learning: A research and practice model," Simulation and Gaming, 33(4), 2002, pp. 441-467.

27. FrogAsia, Panduan Jurulatih - Modul 1. Kuala Lumpur: FrogAsia Sdn Bhd, 2014.

28. Ministry of Education (MoE) Malaysia, Laporan tahunan 2015 Pelan Pembangunan Pendidikan Malaysia 2013-2025. Putrajaya: MoE, 2016.

29. C. Cheong, F. Cheong, and J. Filippou, "Quick quiz: A gamified approach for enhancing learning," Pacific Asia Conference on Information Systems, 2013, pp. 1-15.

30. J. Laskaris, Facts about gamification in elearning. Available: http://elearningindustry.com/30-facts-gamificationinelearning. 